\section{Associate Members cont.}

N.V. KEMA, Arnhem, The Netherlands

Kernforschungsanlage Jülich,

Jülich, FRG

Kernforschungszentrum Karlsruhe

GmbH, Karlsruhe, FRG

Masson Editeurs, Paris, France

Max-Planck-Institut für Festkörper-

forschung, Stuttgart, FRG

Netherlands Energy Research

Foundation, Petten. The Netherlands

North-Holland Publishing Co.,

Amsterdam, The Netherlands

Oesterreichische Studiengesellschaft für

Atomenergie $\mathrm{GmbH}$, Vienna, A

* Oldelft, Delft, The Netherlands

Pechiney, Ugine, Kuhimann,

Paris, France

N.V. Philips' Gloeilampenfabrieken, Eindhoven, The Netherlands

Physikalisch-Technische Bundesanstalt, Braunschweig, FRG

Laboratories RCA Ltd., Zürich, $\mathrm{CH}$

Renault, Rueil Malmaison, France

Research Institute of the Swedish $\mathrm{Na}$ tional Defence, Stockholm, Sweden

Rhône-Poulenc, Courbevoie, France

Risø National Laboratory,

Roskilde, DK

Siemens Aktiengesellschaft, Berlin and

Munich, Fed. Rep. of Germany

SIN - Swiss Institute for Nuclear

Research, Villigen, Switzeriand

Springer Verlag GmbH \& Co. KG, Heidelberg, FRG

Taylor \& Francis Ltd., London, UK

Thomson CSF, Paris, France

TNO - Netherlands Organisation for

Applied Scientific Research,

The Hague, NL

UK Atomic Energy Authority,

London, UK

URANIT, Jülich, FRG

* New members

The statement opposite was forwarded by the President of EPS on 22 June 1982 to the representatives of the Governments of the USA and the USSR in Geneva.

\title{
Statement of European Physicists
}

The purpose of the European Physical Society is to contribute to, and promote the advancement of physics in Europe and in neighbouring countries. As a body we integrate all the European Physical Societies, North and South, East and West from a total of 30 countries.

In the past, scientific advances for which physicists have been largely responsible have contributed substantially to the well-being of mankind. Regrettably some of our discoveries have led to the creation of weapons of mass destruction.

As physicists we know better than any one else the power of these weapons which can, in minutes, ruin our civilization, kill most living beings and cripple the progeny of those left. By their very presence these weapons already destabilize peace, instil fear and insecurity.

Being scientists and engineers we are fully aware of the logic that leads to the development of weaponry and we are deeply convinced that it is hopeless through an arms race to resolve political problems or increase our security. With growing concern we notice the tremendous expense both material and moral, that is uselessly detracting from effort which should be directed to the major social and economic issues facing us all.

As people of Europe we can note that our continent could be a theatre of war and we, expendable hostages in a global conflict. We should like to recall the resolution written by two great Europeans - Russel and Einstein in their Manifesto 27 years ago and signed by leading physicists of that time:

"In view of the fact that in any future world war nuclear weapons will certainly be employed, and that such weapons threaten the continued existence of mankind, we urge Governments of the world to realize and to acknowledge publicly that their purpose cannot be furthered by a world war, and we urge them consequently to find peaceful means for the settlement of all matters of dispute between them".

Today peace in the world is at stake. The talks shortly to take place in Geneva are to be concerned with the meaning of detente and the establishment of that understanding which can lead to means of maintaining world security. The peaceful life and work of hundreds of millions of people hang upon the outcome of those talks.

The Executive Committee of the European Physical Society meeting in Geneva on 18th June 1982 calls to those statesmen engaged in the Geneva talks to bring an end to the arms race and to bring about a reduction in the level of nuclear armaments as a first step for creating that atmosphere of political trust in which all means of nuclear warfare can be abolished, so that warfare itself can be finally eliminated.

Geneva, 18 June 1982
EPS Divisions, Sections and Group Astronomy and Astrophysics Division Solar Physics Section

Atomic and Molecular Physics Division

Atomic Spectroscopy Section

Chemical Physics

Electronic and Atomic Collisions

Molecular Physics

Computational Physics Group

Condensed Matter Division

Low Temperature Physics Section

Macromolecular Physics

Magnetism

Metal Physics

Semiconductors and Insulators

Surfaces and Interfaces

High Energy \& Particle Physics Division

Nuclear Physics Division

Plasma Physics Division

Quantum Electronics Division
Europhysics News is the official journal of the European Physical Society which comprises 29 National Societies, Academies and Groups, over 3000 Individual Members and 45 Associate Members. Governing bo dies of EPS are the General Meeting. Council and an elected Executive Committee responsible for detailed policy. EPS promotes the collaboration of physicists throughout Europe, organising and harmonising conferences, and promotes international exchanges in phy sics including participation in research and teaching sics including participation in research and teaching blishes in addition to EN, Europhysics Conference Abstracts, E. Ed. News and, in collaboration with The Institute of Physics (UK), the European Journal of Physics. Individual Members receive EN free of charge (price to institutions: Sw.Fr, 82. - /al, rebates on the price of many publications and on conference fees. An nual subscription to EPS from Individual Members who belong to one of the EPS member societies is: Sw. Fr. 36. - ; for independent members: Sw.Fr. 126.
Editor: E.N. Shaw

Meetings Compilation: W.S. Newman

Editarial Board

K. Appert, A. Baratoff. G.J. Béné.

G.R. Macleod, A. Maeder, J. Muller

Editorial and Advertising Office at the EPS Secretariat.

Address: EUROPEAN PHYSICAL SOCIETY P. O. Box 69, CH-1213 Petit-Lancy 2 Switzerland

Telephone: Geneva (22) 931130

Telex: 23455 alarm ch

Cables: europhys genève

Printed by: Pfirter frères SA CH - 1213 Petit-Lancy/Switzerland 